\title{
Distribution and Characterization of Monilinia spp. Causing Apple Fruit Decay in Serbia
}

Miljan Vasić and Ivana Vico, University of Belgrade, Faculty of Agriculture, Belgrade 11080, Serbia; Wayne M. Jurick II, USDA-ARS, Food Quality Laboratory, Beltsville, MD; and Nataša Duduk, ${ }^{\dagger}$ University of Belgrade, Faculty of Agriculture, Belgrade 11080, Serbia

\begin{abstract}
Brown rot, caused by Monilinia spp., is an economically important preand postharvest disease of pome and stone fruits worldwide. In Serbia, apple is the most widely grown pome fruit, and the distribution of economically important Monilinia spp. responsible for apple brown rot is unknown. Hence, we conducted a three year survey, from 2010 to 2012, where 349 isolates were obtained from six orchards and four storage facilities from five different apple cultivars with brown rot symptoms. Morphological characterization of the isolates, multiplex PCR, and phylogenetic

analysis revealed four species: $M$. fructigena, $M$. laxa, $M$. fructicola, and Monilia polystroma. All species were found in the orchard and in storage, with $M$. fructigena predominating, followed by $M$. polystroma. Representative isolates were analyzed in vitro and in vivo where differences in growth rate, sporulation, and virulence on apple fruit were observed. Findings from this investigation demonstrate diversity in the species responsible for preand postharvest apple brown rot, which has significant implications for pathogen detection and for developing disease-specific management strategies.
\end{abstract}

Brown rot is caused by Monilinia spp. and is one of the most destructive pre- and postharvest diseases of pome and stone fruits (Batra 1991; Byrde and Willetts 1977; Holb and Scherm 2007; van Leeuwen et al. 2000). Economic losses ranging from 7 to $25 \%$ and from 0.6 to $8 \%$ were found in orchards and storage facilities in Europe, respectively (Berrie and Holb 2014). Species distribution and prevalence differ depending on the geographic region, origin, and host. For instance, M. fructigena (Aderhold and Ruhland) is the most important causal agent of brown rot of pome fruits in Europe, while it is a quarantine pathogen for North America and Australia (Batra 1991; Byrde and Willetts 1977). M. fructicola (G. Winter) Honey and M. laxa (Aderhold and Ruhland) are prevalent species on stone fruits occasionally affecting pome fruits (Batra 1991; Byrde and Willetts 1977; Peter et al. 2015). Until 2001, M. fructicola was endemic in North and South America and Oceania (Batra 1991; Byrde and Willetts 1977; OEPP/EPPO 2002), when it was introduced in France. In the last decade, this pathogen was detected in most European countries including Serbia (EFSA Panel 2011; Hrustić et al. 2013; Vasić et al. 2012) and China (Zhu et al. 2011, 2016). M. laxa is globally distributed (Batra 1991; Byrde and Willetts 1977). A fourth species, Monilia polystroma van Leeuwen is newly described, originating from Japan, and is closely related to M. fructigena (van Leeuwen et al. 2002). M. polystroma was detected on different pome and stone fruits in Hungary (Petróczy and Palkovics 2009), Czech Republic (OEPP/EPPO 2011), Poland (Poniatowska et al. 2016), Serbia (Vasić et al. 2013), Italy (Martini et al. 2015), Croatia (Di Francesco et al. 2015), and Slovenia (Munda 2015). In Asia, two additional species of Monilinia are distributed on pome and stone fruits: M. yunnanensis (M. J. Hu and C. X. Luo. sp) and M. mumecola (Y. Sasaki and T. Sano) (Harada et al. 2004; Hu et al. 2011; Zhu et al. 2016). A recent study by Zhu et al. (2016) reported a high frequency (20\%) of M. polystroma isolates during a survey for Monilinia spp. in pome fruit producing regions in China.

In Serbia, apple is one of the most widely grown fruit crops. In 2014, harvested area was 23,737 ha with production about 336,313 tons (http://www.fao.org/faostat/en/\#data). Yield is threatened by numerous pathogens including Monilinia spp. Ivanović and Ivanović (2001) reported losses up to $80 \%$ in Serbian organic apple orchards caused by M. fructigena. Distribution of newly introduced pathogens could

${ }^{\dagger}$ Corresponding author: Nataša Duduk; E-mail: natasadukic@yahoo.com

Accepted for publication 28 September 2017.

@ 2018 The American Phytopathological Society change species composition and may increase pre- and postharvest fruit decay. In Serbia, four species are known as causal agents of apple brown rot: $M$. fructigena, $M$. laxa, $M$. polystroma, and $M$. fructicola (Vasić et al. 2012, 2013, 2016), but their frequency and geographic distribution is currently unknown. In another study in Serbia, Hrustić et al. (2015) observed an increased number of $M$. fructicola isolates causing brown rot of stone fruits in 2012 and 2013 following its initial detection in 2011. Similarly, the composition of Monilinia spp. in apple fruit production may also differ. In complex pathosystems, variability in biological features of closely related species could help determine the pathogen's ability to adapt and thrive (Byrde and Willetts 1977). For example, $M$. polystroma is capable of forming thicker, more compact and complex stromata on apple fruit than M. fructigena. This factor alone may enhance the survival of the fungus and increase the amount of primary inoculum available for the next season (Vasić et al. 2016).

Monilinia spp. also have different lifestyles as M. fructicola and $M$. laxa cause both blossom and twig blight and pre- and postharvest fruit rot, while $M$. fructigena and $M$. polystroma are primarily fruit pathogens (Byrde and Willetts 1977; Holb and Scherm 2007; van Leeuwen et al. 2000; Vasić et al. 2016). Fungal growth, as influenced by different ecological factors and available nutrients, contribute to the basic knowledge of fungal pathogens that might provide key information for developing disease-specific management strategies. Sugar content and $\mathrm{pH}$ value of host tissue influences the pathogen's ability to colonize its host, while temperature plays an important role in disease development and epidemiology. Ecological and cultural characteristics concerning newly described and emerging Monilinia spp. and its comparison with other well characterized species has not been conducted in detail. Holb (2004) showed that M. fructigena mycelial growth was faster under lower $\mathrm{pH}$ compared with $M$. polystroma, at $\mathrm{pH}$ values between 2.5 and 6.5. Holb and Chauhan (2004) observed that the optimal carbohydrate sources for mycelial growth rate of $M$. polystroma and M. fructigena were glucose, fructose, and saccharose, while the best nitrogen source was peptone. However, the influence of different temperatures, varying $\mathrm{pH}$ range, and commercially used media were not determined for M. polystroma. The main objectives for the current study were to: 1) identify Monilinia spp. diversity, both pre- and postharvest, from apple fruit of different production areas in Serbia; 2) compare cultural and morphological factors influencing Monilinia spp. growth and reproduction; and 3) assess pathogenic potential and virulence of Monilinia spp. on apple fruit.

\section{Material and Methods}

Sample collection, fungal isolation, and culture storage. In a 3-year survey from 2010 to 2012, apple fruit 'Idared,' 'Golden Delicious,' 'Granny Smith,' 'Elstar,' and 'Jonagold' with brown rot 
symptoms were collected from 15 apple orchards located in Svilajnac, Topola, Bela Crkva, Ruma, Grocka, and Smederevo and six storage facilities located in Svilajnac, Bela Crkva, Grocka and Smederevo (Fig. 1). Isolation was done from the lesion margin after surface sanitization using 70\% ethanol and aseptic removal of the skin. Fragments of tissue were placed onto potato dextrose agar (PDA, EMD Chemicals Inc, Gibbstown, NJ, U.S.A.) amended with $2.5 \mathrm{ml}$ of $25 \%$ lactic acid per liter of medium and incubated at $22^{\circ} \mathrm{C}$ in the dark for 4 days in an incubator. Subsequently, mycelial fragments taken from the growing colony margin were transferred to fresh PDA. Single spore cultures were obtained from conidia produced on V8 medium $(200 \mathrm{ml} \mathrm{V8} \mathrm{juice}$ and $20 \mathrm{~g}$ agar per liter). One isolate, due to the inability to sporulate on either media or inoculated fruit, was propagated by hyphal tip transfer. The isolates were maintained in $15 \%$ glycerol at $-80^{\circ} \mathrm{C}$ as mycelial plugs taken from 7-day-old cultures grown on PDA. Isolates of $M$. fructigena and M. polystroma (Vasić et al. 2016) were also included in this study for comparison (Table 1).

Pathogenicity test and reisolation of Monilinia spp. from apple fruit. Pathogenicity of the isolates was tested on mature Idared fruit. Apples were surface-sanitized by immersing in 1\% solution of sodium hypochlorite $(\mathrm{NaOCl})$ for $2 \mathrm{~min}$ and rinsed twice in sterile distilled water before inoculation. A 5-mm-diameter mycelial plug was taken from the margin of 5-day-old colonies grown on PDA and inserted into a hole ( $6 \mathrm{~mm}$ diameter and $5 \mathrm{~mm}$ depth) in the cortex of each fruit using a cork borer. Apple fruit inoculated with uncolonized PDA plugs were used as controls. Inoculated and control fruit were placed in plastic containers at $22 \pm 1{ }^{\circ} \mathrm{C}$ under high humidity (RH 95 to $100 \%$ ) and alternating $14 \mathrm{~h}$ light $/ 10 \mathrm{~h}$ dark cycles and incubated for 5 days. Three replicates per isolate were used. Reisolation was performed as described above (see sample collection and fungal isolation).

Morphological identification of Monilinia spp. The morphology of each isolate was determined on PDA. Morphological characterization was performed according to van Leeuwen et al. (2002) with slight modifications. For morphological characterization, 5-mmdiameter mycelial plugs were taken from the edge of the 5-day-old colonies and inoculated in the center of a PDA plate. Colony characteristics (color, aerial mycelium, margin shape, presence of reproductive structures, and formation of stroma) of Monilinia spp. isolates were determined on PDA after 12 days of incubation in $12 \mathrm{~h}$ light $/ 12 \mathrm{~h}$ dark cycle at $22 \pm 1{ }^{\circ} \mathrm{C}$ using a fluorescent lamp approximately $15 \mathrm{~cm}$ above the Petri dishes as described by Byrde and Willetts (1977), Batra (1991), and OEPP/EPPO (2009).

DNA extraction and multiplex PCR. Fungal mycelium was obtained from isolates grown on PDA for 7 days. DNA extraction

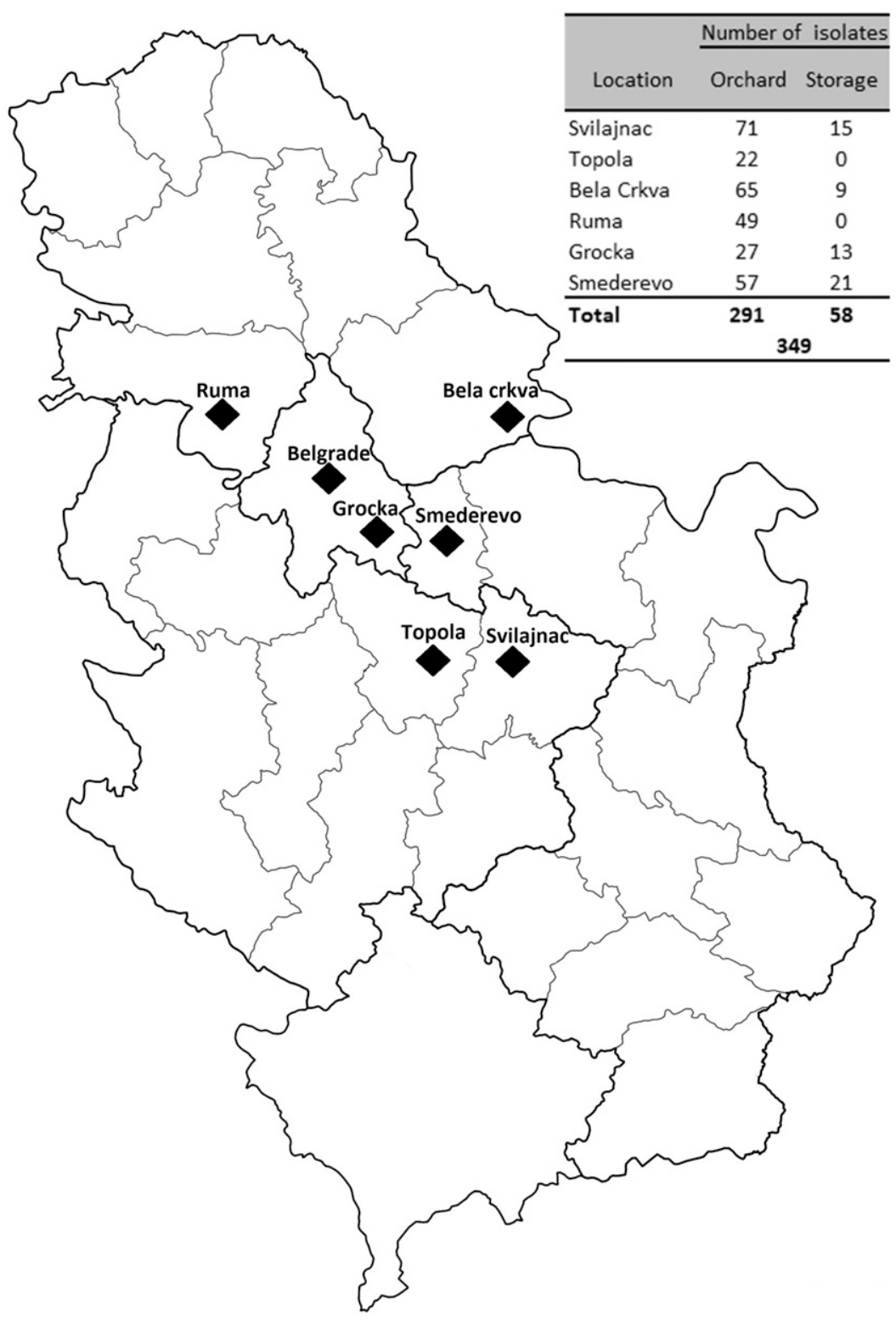

Fig. 1. Monilinia spp. isolates obtained from apple fruit in Serbia. 
was performed following the CTAB protocol of Day and Shattock (1997). Total DNA was precipitated with isopropanol, resuspended in $30 \mu$ of TE buffer (10 mM Tris $\mathrm{pH} 8$ and $1 \mathrm{mM}$ EDTA), and stored at $-20^{\circ} \mathrm{C}$. DNA was amplified via multiplex PCR with primers based on a genomic region of Monilinia spp. with unknown function, forward MO368-5 and three reverse Laxa-R2, MO368-8R, and MO368-10R, which yield products of $402 \mathrm{bp}$ for M. fructigena,
$425 \mathrm{bp}$ for M. polystroma, $535 \mathrm{bp}$ for M. fructicola and $351 \mathrm{bp}$ for M. laxa (Côté et al. 2004). PCR reaction mix $(25 \mu \mathrm{l})$ contained $1 \mu \mathrm{l}$ of template DNA, 1× PCR MasterMix (Fermentas, Vilnius, Lithuania), and $0.2 \mu \mathrm{M}$ of each primer. PCR cycling parameters were as follows: initial denaturation at $95^{\circ} \mathrm{C}$ for $2 \mathrm{~min}$, followed by $35 \mathrm{cy}-$ cles of $95^{\circ} \mathrm{C}$ for $15 \mathrm{~s}, 60^{\circ} \mathrm{C}$ for $15 \mathrm{~s}$, and $72^{\circ} \mathrm{C}$ for $1 \mathrm{~min}$, with final extension at $72^{\circ} \mathrm{C}$ for $3 \mathrm{~min}$. The PCR product $(5 \mu \mathrm{l})$ was separated in

Table 1. Monilinia spp. isolates and rDNA-ITS region sequences used in this study

\begin{tabular}{|c|c|c|c|c|}
\hline Isolates & Species & Geographic origin & Host & GenBank accession number \\
\hline \multicolumn{5}{|l|}{ Isolates from Serbia } \\
\hline MPSRB- $2 \mathrm{G}^{\mathrm{u}, \mathrm{w}, \mathrm{x}}$ & M. polystroma & Bela Crkva & Apple & KP279655 \\
\hline MPSRB-20 $0^{\mathrm{u}, \mathrm{v}, \mathrm{w}, \mathrm{x}}$ & M. polystroma & Bela Crkva & Apple & KP279656 \\
\hline MPSRB-13 $3^{\mathrm{u}, \mathrm{v}, \mathrm{w}, \mathrm{x}}$ & M. polystroma & Bela Crkva & Apple & KP279657 \\
\hline MPSRB-13A $\mathrm{A}^{\mathrm{u}, \mathrm{w}, \mathrm{x}}$ & M. polystroma & Bela Crkva & Apple & JX315717 \\
\hline MPSRB- $3^{\mathrm{u}, \mathrm{w}, \mathrm{x}}$ & M. polystroma & Bela Crkva & Apple & KP279658 \\
\hline MPSRB- $2^{\mathrm{u}, \mathrm{w}, \mathrm{x}}$ & M. polystroma & Bela Crkva & Apple & KP279659 \\
\hline MPSRB- $36^{\mathrm{u}, \mathrm{v}, \mathrm{w}, \mathrm{x}}$ & M. polystroma & Bela Crkva & Apple & KP279660 \\
\hline MPSRB-6 ${ }^{\mathrm{w}}$ & M. polystroma & Bela Crkva & Apple & $\mathrm{nd}^{\mathrm{z}}$ \\
\hline MPSRB- $21^{\mathrm{w}}$ & M. polystroma & Bela Crkva & Apple & nd \\
\hline MFSRB- $1^{\mathrm{u}, \mathrm{w}, \mathrm{x}}$ & M. fructigena & Svilajnac & Apple & KP279661 \\
\hline MFSRB- $10^{\mathrm{u}, \mathrm{w}, \mathrm{x}}$ & M. fructigena & Bela Crkva & Apple & KP279662 \\
\hline MFSRB-17 $7^{\mathrm{u}, \mathrm{v}, \mathrm{w}, \mathrm{x}}$ & M. fructigena & Grocka & Apple & KP279663 \\
\hline MFSRB-2 $2^{\mathrm{u}, \mathrm{w}, \mathrm{x}}$ & M. fructigena & Grocka & Apple & KP279664 \\
\hline MFSRB-32 $2^{\mathrm{u}, \mathrm{w}, \mathrm{x}}$ & M. fructigena & Svilajnac & Apple & KP279665 \\
\hline MFSRB- $6^{\mathrm{u}, \mathrm{v}, \mathrm{w}, \mathrm{x}}$ & M. fructigena & Svilajnac & Apple & KP279666 \\
\hline MFSRB- $3^{\mathrm{u}, \mathrm{w}, \mathrm{x}}$ & M. fructigena & Topola & Apple & KP279667 \\
\hline MFSRB-22 $2^{\mathrm{u}, \mathrm{v}, \mathrm{w}, \mathrm{x}}$ & M. fructigena & Bela Crkva & Apple & KP279668 \\
\hline MFSRB-6SD ${ }^{w}$ & M. fructigena & Smederevo & Apple & nd \\
\hline MFSRB-8SDw & M. fructigena & Smederevo & Apple & nd \\
\hline MFC- $20^{\mathrm{u}, \mathrm{v}, \mathrm{w}}$ & M. fructicola & Grocka & Apple & JN176564 \\
\hline MFC- $28^{\mathrm{u}, \mathrm{w}}$ & M. fructicola & Ruma & Apple & KN695550 \\
\hline MFC- $1^{\mathrm{v}, \mathrm{w}}$ & M. fructicola & Smederevo & Apple & nd \\
\hline MLX-SV1 $1^{\mathrm{u}, \mathrm{w}}$ & M. laxa & Svilajnac & Apple & KP279669 \\
\hline MLX-7u,w & M. laxa & Svilajnac & Apple & KN695549 \\
\hline MLX-13 $3^{v, w}$ & M. laxa & Smederevo & Apple & nd \\
\hline MLX-24 $4^{\mathrm{v}, \mathrm{w}}$ & M. laxa & Ruma & Apple & nd \\
\hline \multicolumn{5}{|c|}{ Sequences from $\mathrm{NCBI}^{\mathrm{y}}$} \\
\hline $16 \mathrm{FG}$ & M. fructigena & Hungary & Apple & AM937110 \\
\hline SPBA & M. fructigena & Serbia & Plum & KC544805 \\
\hline LAI1B & M. fructigena & France & Apple & AF150677 \\
\hline 759.K & M. fructigena & Unknown & Apple & $\mathrm{Z73779}$ \\
\hline COY2M & M. fructigena & France & Plum & AF150680 \\
\hline $770 . \mathrm{S}$ & M. fructigena & Unknown & Apple & $\mathrm{Z73780}$ \\
\hline ES41 & M. fructigena & Spain & Unknown & EF207429 \\
\hline W17 & M. fructigena & Spain & Unknown & EF207424 \\
\hline UFT & M. polystroma & Hungary & Apple & AM937114 \\
\hline AP1 & M. polystroma & Poland & Apple & JF820317 \\
\hline 09-G4 & M. polystroma & Switzerland & Apricot & JN128835 \\
\hline 2319 & M. polystroma & Japan & Unknown & HQ856916 \\
\hline HML-3 & M. polystroma & China & Plum & GU067539 \\
\hline P169 & M. fructicola & Italy & Nectarine & FJ411109 \\
\hline LMK12 & M. fructicola & Unknown & Peach & Z73777 \\
\hline M 10020029 & M. fructicola & Slovenia & Peach & GU967379 \\
\hline SPT16 & M. fructicola & China & Peach & HQ846920 \\
\hline NPUD1 & M. fructicola & Serbia & Nectarine & KC544808 \\
\hline M1PL & M. fructicola & Poland & Unknown & JX312665 \\
\hline SFT1 & M. fructicola & China & Unknown & HQ846921 \\
\hline 1067. K & M. laxa & Unknown & Apple & Z73784 \\
\hline BPZK & M. laxa & Serbia & Peach & KC544793 \\
\hline L2 & M. laxa & Spain & Unknown & EF153013 \\
\hline $\mathrm{T} 3$ & M. laxa & Spain & Unknown & EF153014 \\
\hline LUC1A & M. laxa & France & Plum & $\mathrm{AF} 150673$ \\
\hline BF-SZ-1 & M. laxa & China & Peach & HQ908790 \\
\hline
\end{tabular}

u Isolates used in phylogenetic analysis.

${ }^{\mathrm{v}}$ Isolates used for cultural and ecological tests.

${ }^{\mathrm{w}}$ Isolates used in virulence and sporulation tests.

${ }^{\mathrm{x}}$ Identified isolates used in virulence test (Vasić et al. 2016).

y National Center for Biotechnology Information.

${ }^{\mathrm{z}}$ nd: Sequence was not determined. 
a $1.5 \%$ agarose gel, stained with ethidium bromide, and visualized with a UV transilluminator.

PCR-RFLP analysis. PCR-RFLP was conducted according to the method described by Vasić et al. (2016). The ITS1-5.8S-ITS2 region was amplified with the universal primer pair ITS1/ITS4 (White et al. 1990). PCR reaction mix ( $25 \mu \mathrm{l})$ contained $1 \mu \mathrm{l}$ of template DNA, $1 \times$ PCR MasterMix (Fermentas, Vilnius, Lithuania), and $0.4 \mu \mathrm{M}$ of each primer. Cycling parameters for the ITS region consisted of: initial denaturation at $94^{\circ} \mathrm{C}$ for $90 \mathrm{~s}$, followed by 30 cycles of $94^{\circ} \mathrm{C}$ for $30 \mathrm{~s}$, $55^{\circ} \mathrm{C}$ for $30 \mathrm{~s}$, and $72^{\circ} \mathrm{C}$ for $30 \mathrm{~s}$, and final extension at $72^{\circ} \mathrm{C}$ for 10 min. RFLP analysis of ITS1/ITS4-amplified PCR products ( $550 \mathrm{bp})$ of Monilinia spp. isolates (Fig. 1) was performed using $\mathrm{HhaI}$ restriction endonuclease (Fermentas, Vilnius, Lithuania), according to the manufacturer's instructions. RFLP products were separated on a $2 \%$ agarose gel, stained using ethidium bromide, and visualized with a UV transilluminator.

Sequence analysis of rDNA-ITS region and phylogeny. Amplified ITS1/ITS4 products ( $550 \mathrm{bp})$ were purified using mi-PCR Purification Kit (Metabion International AG, Germany) and sequenced using ITS1 and ITS4 primers. Sequences were assembled using Pregap4 from the Staden program package (Staden et al. 2000), aligned using Clustal X (Thompson et al. 1997) under MEGAversion 5 (Tamura et al. 2011), and $2 \times$ consensus was deposited in GenBank. Sequences were compared with others in GenBank using the MegaBlast algorithm. Phylogenetic analysis of 19 sequences from Serbian apple fruit and 24 reference sequences were retrieved from GenBank from published sources (Table 1) was performed for the noncoding region (ITS15.8S-ITS2). For constructing the ITS phylogenetic tree, Botryotinia fuckeliana sequence was designated as an outgroup. Maximum parsimony (MP) was performed to carry out phylogenetic construction using MEGA version 6.0 (Tamura et al. 2013). Bootstrap values were estimated by 1000 replicates to test clade stability.

Effect of different media on mycelial growth and sporulation of Monilinia spp. Mycelial growth of selected isolates was evaluated on five different media. PDA (EMB Chemicals Inc., Gibbstown, NJ, U.S.A.) and Czapeck dox agar (CYA, Honeywell Fluka, Seelze, Germany) were prepared according to the manufacturer's instructions. Malt extract agar (MEA) was prepared from $20 \mathrm{~g}$ malt extract (Sigma-Aldrich) and $15 \mathrm{~g}$ agar by adding 1 liter of distilled water according to procedure described by Kim et al. (2005). Apple juice agar (AJA) was prepared by adding $200 \mathrm{ml}$ of apple juice in $800 \mathrm{ml}$ of distilled water, and adding $3 \mathrm{~g} \mathrm{CaCO}_{3}$ and $15 \mathrm{~g}$ agar according to procedure described by Kim et al. (2005). V8 agar (V8) was prepared by adding $200 \mathrm{ml}$ of V8 juice in $800 \mathrm{ml}$ of distilled water, and adding $3 \mathrm{~g} \mathrm{CaCO}_{3}$ and $15 \mathrm{~g}$ agar according to procedure described by Gams et al. (1987). The media were sterilized for $20 \mathrm{~min}$ at $121^{\circ} \mathrm{C}$ using an autoclave. Isolates were maintained on PDA for 5 days. Mycelial plugs, $5 \mathrm{~mm}$ in diameter, were removed from the growing edge of the colony and inoculated in the center of a Petri plate containing PDA medium. Subsequently, plates were wrapped with Parafilm and placed in incubators at $25^{\circ} \mathrm{C}$. Mean colony diameter, excluding the plug, was measured daily and growth rate was expressed as mm of growth per day. Sporulation intensity was assessed according to method described by $\mathrm{Hu}$ et al. (2011) with slight modifications. After 7 days of incubation, plates were flooded with $5 \mathrm{ml}$ of sterile distilled water and the colonies were softly scraped with a glass rod. Conidial suspensions were filtered through a double layer of cheesecloth and conidial concentration was determined using a hemacytometer and compound light microscope. The number of conidia produced per $\mathrm{cm}^{2}$ for each colony was calculated as a quotient of the number of conidia produced per colony and colony area. Five replicates per isolate were used and the entire assay was done twice.

Effect of temperature and $\mathrm{pH}$ on mycelial growth of Monilinia spp. The effect of various incubation temperatures ranging from 5 to $35^{\circ} \mathrm{C}$ on mycelial growth of select representative isolates was evaluated on PDA. Inoculum and inoculation of different media were done as described above (see effect of different media on mycelial growth and sporulation). Mean colony growth per day was calculated as described above (see effect of different media on mycelial growth). Five replicates per isolate were used and the experiment was done twice. The effect of different culture $\mathrm{pH}$ on mycelial growth of representative isolates was evaluated on PDA. Different $\mathrm{pH}$ values ranging from 3 to 9 were adjusted using a $\mathrm{pH}$-meter (InoLab pH 220, Xylem Analytics, Germany) by adding 0.1 N HCL or $0.1 \mathrm{~N} \mathrm{NaOH}$ into the medium. After autoclaving and cooling, $\mathrm{pH}$ was verified with $\mathrm{pH}$ test strips (universal indicator, $\mathrm{pH}$ 0-14, Merck, Germany). Inoculum and inoculation of different media were done as described above (see effect of different media on mycelial growth). Inoculated plates were incubated at $25^{\circ} \mathrm{C}$. Mean colony growth per day was calculated as described above (see effect of different media on mycelial growth). Five replicates per isolate were used and the experiment was done twice.

Virulence test and sporulation intensity on apple fruit. Analysis of pathogen virulence was conducted using a representative isolate of each of the four Monilinia spp. Mature apple fruit Golden Delicious, Idared, and Granny Smith were wound-inoculated as described in the pathogenicity test. Lesion size was measured at equatorial and longitudinal axes 5 days postinoculation. Sporulation intensity was assessed according to the method described by van Leeuwen et al. (2002) with slight modifications. Six days after incubation, conidia were collected by shaking fruit in $30 \mathrm{ml}$ of sterile distilled water at $250 \mathrm{rpm}$ for $30 \mathrm{~s}$ in an orbital shaker. Conidial suspensions were filtered through a double layer of cheesecloth and conidial concentration was determined using a hemacytometer and compound light microscope. The total number of conidia produced per fruit was calculated by multiplying the number of conidia per $\mathrm{ml}$ with the collected volume in $\mathrm{ml}$. The number of conidia produced per $\mathrm{cm}^{2}$ of lesion was calculated as a quotient of the number of conidia produced per fruit and lesion area. Sporulation data were logtransformed for statistical analysis. Six replicates per isolate were tested and the experiment was conducted twice.

Statistical analysis. All experiments were conducted at least twice. To determine whether the data from two experiments could be combined, the analysis of variance (ANOVA) was used to test homogeneity of variance. If data from both runs of each experiment were not significantly different, then they were combined. Conidial production data were log transformed before analysis so not to violate the ANOVA assumption. All analyses were performed with STATGRAPHICS (Centurion StatPoint 2005). Treatment means were separated using Tukey post hoc test. Virulence was analyzed with two-factor ANOVA testing the influence of species and cultivars on lesion size. Statistical significance for all tests was defined as $P<0.05$.

\section{Results}

Monilinia spp. isolate origin and pathogenicity on apple. During a three-year study from 2010 to 2012, 291 Monilinia spp. isolates were obtained from symptomatic apple fruit collected in six orchards and 58 from four storage facilities, totaling 349 isolates. All inoculated apples showed symptoms of brown rot 5 days postinoculation, while control fruit remained symptomless, indicating their pathogenic capability. Lesion areas were brown with entire to slightly undulate margins. On decayed areas, numerous yellow sporodochia or white mycelia with sparse sporulation were observed. On some fruit, around inoculation sites, grayish conidial masses were evident. In total, 349 reisolates of Monilinia spp. were obtained from symptomatic apples, both pre- and postharvest (Fig. 1).

Cultural morphology. Colony morphology of isolates on PDA indicated the presence of four distinct phenotypes (Fig. 2). It was observed that 236 isolates formed whitish colonies with entire to slightly undulate margins, with sparse aerial mycelia, did not sporulate on PDA medium, and lacked stromatization in the colony reverse. These isolates were later confirmed to be $M$. fructigena. Thirty-three isolates formed grayish colonies with entire to slightly undulate margins, while aerial mycelia were sparse, and sporulation was not observed. The reverse exhibited mycelial pigmentation along with minor stromatization and were later considered $M$. fructigenal M. polystroma. Forty-eight isolates formed grayish colonies with entire to slightly undulate margins, while aerial mycelia were sparse and 
sporulation was not evident. The colony reverse developed black stromatal plates in concentric rings around inoculation points and were later considered to be $M$. polystroma. Nineteen isolates were whitish to gray with lobed margins and were devoid of sporulation and stromatization. These isolates were later identified as M. laxa. Thirteen isolates formed grayish colonies, developing spore masses in concentric rings, colony margins were even, and colony reverse without stromatization and were labeled M. fructicola.

Molecular identification and phylogeny. Molecular identification using multiplex PCR confirmed the morphological identification of four Monilinia spp. Two hundred sixty-nine isolates (first and second morphological group) were identified as $M$. fructigena (402-bp amplicon), 48 as M. polystroma (421-bp amplicon), 19 as M. laxa (325-bp amplicon), and 13 as M. fructicola (535-bp amplicon). RFLP analysis using ITS1/ITS4 amplicon digested with HhaI restriction enzyme yielded RFLP profiles of $M$. polystroma, which were distinct from other Monilinia spp. Phylogenetic analysis based on the ITS sequences revealed divergent clusters for each species, while $M$. fructigena and $M$. polystroma were more closely related (Fig. 3). A phylogenetic tree based on ITS sequences also
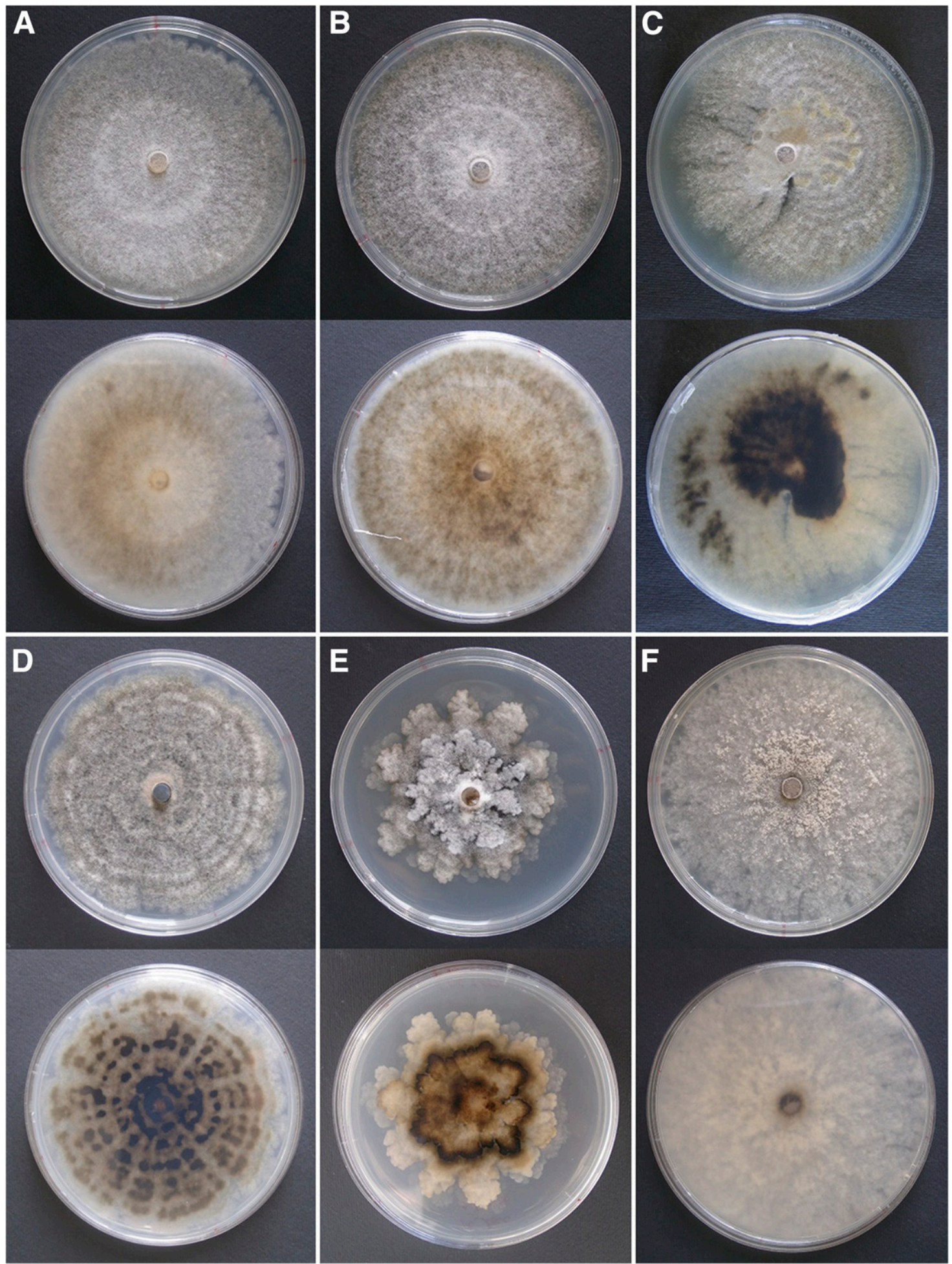

Fig. 2. Colony characteristics of Monilinia spp. grown on PDA in $12 \mathrm{~h}$ light/12 $\mathrm{h}$ dark regime after 12 days of incubation. A, B, C, M. fructigena (MFSRB-1, MFSRB-22, and MFSRB32); D, M. polystroma (MPSRB-20); E, M. laxa (MLX-13); and F, M. fructicola (MFC-1). 
revealed high bootstrap values within each clade, and provided an indication of strong phylogenetic relationships between Monilinia spp. causing pre- and postharvest apple decay.

Diversity of Monilinia spp. causing apple brown rot in Serbia. In Serbian apple orchards the dominant causal agent of brown rot was $M$. fructigena (76.98\%), followed by M. polystroma (14.78\%), M. laxa $(5.15 \%)$, and M. fructicola (3.09\%) (Table 2). In results from the 2011 survey for Monilinia spp. in Bela Crkva region, M. polystroma was detected in more samples $(62.07 \%)$ than $M$. fructigena $(33.93 \%)$, while similar trends were observed in 2012 as $69.45 \%$ were $M$. polystroma compared with $M$. fructigena at $30.55 \%$. Under storage conditions, $M$. fructigena was the dominant species $(77.58 \%)$, followed by $M$. polystroma (8.62\%), M. fructicola (6.9\%), and M. laxa $(6.9 \%)$ (Table 2).
Characterization of growth rate on different media, temperatures, and pH levels in vitro. Culture media affected the mycelial growth of Monilinia spp. in vitro $(P<0.05)$. M. fructigena, $M$. polystroma, $M$. laxa, and $M$. fructicola exhibited the fastest growth on V8 and PDA, but grew slower on AJA, MEA, and CYA (Table 3). The slowest isolate MFSRB-6 ( $M$. fructigena) had a similar growth rate on all media. Isolates of $M$. fructigena, $M$. polystroma, and $M$. laxa sporulated only on V8 media (Table 4), whereas isolates of $M$. fructicola sporulated on all media examined. Optimal media for $M$. fructicola sporulation were PDA and V8, followed by MEA, while CYA and AJA were all less favorable. Temperature also affected mycelial growth of Monilinia spp. in vitro $(P<0.05)$. All isolates grew at temperatures from 5 to $30^{\circ} \mathrm{C}$, while no growth was observed at $35^{\circ} \mathrm{C}$ (Fig. 4). Slowest growth was observed at $5^{\circ} \mathrm{C}$, and optimal temperature

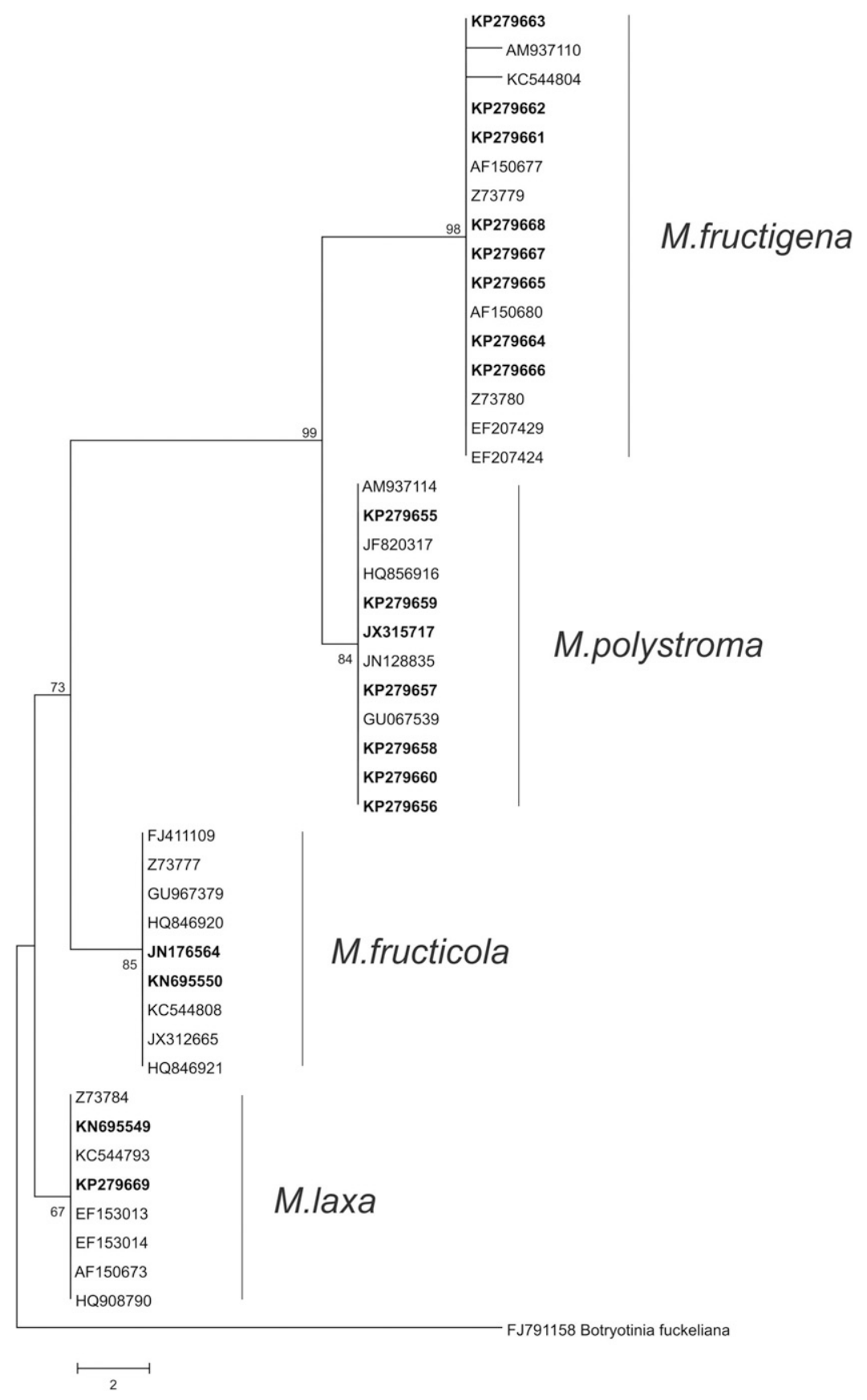

Fig. 3. Phylogenetic tree of rDNA region ITS1-5.8S-ITS2 for 19 Monilinia spp. isolates originating from apple fruit and 24 reference isolates from GenBank. Botryotinia fuckeliana was used as an outgroup. The tree was constructed using the maximum parsimony method and bootstrap values more than 60 are shown above or below branches. The scale represents number of changes. 
occurred at $25^{\circ} \mathrm{C}$ for all isolates. M. polystroma grew the fastest between 15 and $25^{\circ} \mathrm{C}$, while isolates of $M$. fructigena, M. laxa, and M. fructicola grew optimally between 20 and $30^{\circ} \mathrm{C}$. Culture $\mathrm{pH}$ significantly impacted fungal growth in vitro $(P<0.05)$ (Fig. 5). Optimal $\mathrm{pH}$ for $M$. fructigena occurred between 3 and $4, M$. polystroma 3 to 6 , $M$. fructicola between 6 and 8, and M. laxa between 5 and 8 .

Analysis of virulence and sporulation in different commercial apple cultivars. A significant influence of species and apple cultivar on lesion size $(P<0.05)$ was detected via two-factor ANOVA. Interaction between isolates of four species and cultivars was also significantly different $(P=0.004)$. Four species produced larger lesions on Golden Delicious than on Idared and Granny Smith (Fig. 6A). On Golden Delicious, $M$. fructigena and $M$. polystroma were the most virulent and did not differ significantly $(P=0.406)$. $M$. laxa had lower virulence, while $M$. fructicola was the least virulent. On Idared, M. fructigena was the most virulent, M. fructicola the least, while $M$. polystroma exhibited differences in virulence where lesion size was not significantly different from $M$. fructigena $(P=0.219)$ and $M$. laxa $(P=0.378)$. On Granny Smith, $M$. fructigena was most virulent, followed by $M$. polystroma, as $M$. fructicola was least virulent. $M$. laxa exhibited variability in lesion size and was not significantly different from M. polystroma $(P=0.938)$ and $M$. fructicola $(P=0.256)$.

Table 2. Geographic distribution of Monilinia spp. isolates from apple fruit in Serbia

\begin{tabular}{llll}
\hline & & \multicolumn{2}{c}{ Number of isolates } \\
\cline { 3 - 4 } Species & Location & Orchard & Storage \\
\hline M. fructigena & Svilajnac & 69 & 15 \\
& Smederevo & 49 & 17 \\
& Grocka & 20 & 9 \\
& Bela Crkva & 22 & 4 \\
& Ruma & 42 & $-\mathrm{z}$ \\
& Topola & 22 & - \\
M. laxa & Total (\%) & $224(76.98)$ & $45(77.58)$ \\
& Svilajnac & 2 & 0 \\
& Smederevo & 5 & 4 \\
& Grocka & 4 & 0 \\
M. fructicola & Ruma & 4 & - \\
& Total (\%) & $15(5.15)$ & $4(6.9)$ \\
& Smederevo & 3 & 0 \\
& Grocka & 3 & 4 \\
M. polystroma & Ruma & 3 & - \\
& Total (\%) & $9(3.09)$ & $4(6.9)$ \\
& Bela Crkva & 43 & 5 \\
& Total (\%) & $43(14.78)$ & $5(8.62)$ \\
\hline
\end{tabular}

z '-' indicates that diseased apple fruit were not collected and isolates were not obtained.
A two-factor ANOVA revealed a statistically significant effect of species and apple cultivar on sporulation intensity $(P<0.05)$. Interaction between isolates of four species and cultivars was significantly different $(P=0.001)$. Four species had higher sporulation on Idared and Golden Delicious compared with Granny Smith (Fig. 6B). On Idared, $M$. fructigena and $M$. fructicola sporulated abundantly and did not differ statistically $(P=0.995)$, followed by $M$. polystroma, which sporulated at a lower amount. On Golden Delicious, all species sporulated similarly as on Idared, whereas M. fructicola and M. fructigena had the highest sporulation intensity $(P=0.357)$, followed by $M$. polystroma, which had slightly lower sporulation. On Granny Smith, M. fructicola had the most abundant sporulation, followed by $M$. fructigena and $M$. polystroma, which did not differ significantly $(P=0.528)$. In comparison with other tested species, $M$. laxa had the lowest sporulation levels on three different apple cultivars.

\section{Discussion}

During a three-year sampling period from 2010 to 2012, M. fructigena was the dominant causal agent of apple brown rot both preand postharvest in Serbia, followed by M. polystroma, M. laxa, and $M$. fructicola. Distribution of Monilinia spp. in complex pathosystems, where more than one species is present, has been shown primarily in stone fruit-producing regions. Michailides et al. (1987) observed increased populations of $M$. fructicola compared with M. laxa in California, which mirrors what was found in European countries such as Spain, Greece, and Serbia (Hrustić et al. 2015; Papavasileiou et al. 2015; Villarino et al. 2013). However, in Poland, $M$. fructigena was most prevalent on apricot, peach, and plum, while the incidence of M. laxa, M. fructicola, and M. polystroma was low (Poniatowska et al. 2013). Distribution of Monilinia spp. in apple and pear fruit production has recently been described in China by Zhu et al. (2016). Interestingly, the brown rot species composition on pomes in China was different from Serbia, where the dominant species was M. yunnanensis (77\%), followed by M. polystroma (20\%) and $M$. fructicola (3\%). M. polystroma was detected only in eastern China, while $M$. fructigena was undetected. In contrast, we have observed that $M$. fructigena is the main agent of apple brown rot in Serbia, which is in agreement with literature for other European countries (Holb and Scherm 2007; van Leeuwen et al. 2000).

$M$. polystroma is a newly threatening species for apple fruit production in Serbia, since more isolates of $M$. polystroma were detected 2012 compared with 2011 in Bela Crkva region. There is limited data about the potential spread of M. polystroma, which is very similar to $M$. fructigena, making it potentially dangerous since $M$. fructigena is a quarantine species for North America and Australia and also causes significant production losses in Europe. Research by Vasić et al. (2013) showed that M. polystroma occurred in apple orchards in Serbia, but in the current study, for the first time, we found this species in storage on apple fruit 4 months after harvest. Monilinia spp.

Table 3. Mycelial growth rate of Monilinia spp. isolates on five media at $25^{\circ} \mathrm{C}$ in the dark

\begin{tabular}{|c|c|c|c|c|c|c|}
\hline \multirow[b]{2}{*}{ Species } & \multirow[b]{2}{*}{ Isolate } & \multicolumn{5}{|c|}{ Colony growth rate on culture media $(\mathrm{mm} / \mathrm{day} \pm \mathrm{SE})^{\mathrm{u}}$} \\
\hline & & MEA $^{\mathbf{v}}$ & $\mathbf{A J A}^{\mathbf{w}}$ & PDA $^{\mathbf{x}}$ & CYA $^{\mathbf{y}}$ & $\mathbf{V 8}^{\mathbf{z}}$ \\
\hline \multirow[t]{3}{*}{ M. fructigena } & MFSRB-17 & $6.93 \pm 0.43 \mathrm{a}$ & $6.83 \pm 0.14 \mathrm{a}$ & $10.71 \pm 0.25 \mathrm{bc}$ & $7.19 \pm 0.37 \mathrm{a}$ & $11.92 \pm 0.08 \mathrm{c}$ \\
\hline & MFSRB-22 & $4.07 \pm 0.15 \mathrm{ab}$ & $3.56 \pm 0.54 \mathrm{a}$ & $7.81 \pm 0.92 \mathrm{bc}$ & $4.59 \pm 0.42 \mathrm{ab}$ & $8.15 \pm 0.26 \mathrm{c}$ \\
\hline & MFSRB-6 & $1.93 \pm 0.46 \mathrm{ab}$ & $0.96 \pm 0.58 \mathrm{a}$ & $1.29 \pm 0.10 \mathrm{ab}$ & $0.74 \pm 0.36 \mathrm{a}$ & $1.33 \pm 0.41 \mathrm{ab}$ \\
\hline \multirow[t]{3}{*}{ M. polystroma } & MPSRB-36 & $4.36 \pm 0.89 \mathrm{ab}$ & $3.18 \pm 0.27 \mathrm{a}$ & $6.12 \pm 1.09 \mathrm{bc}$ & $3.99 \pm 0.64 \mathrm{a}$ & $7.88 \pm 0.60 \mathrm{c}$ \\
\hline & MPSRB-13 & $4.81 \pm 0.10 \mathrm{ab}$ & $3.55 \pm 0.14 \mathrm{a}$ & $7.81 \pm 0.49 b c$ & $3.4 \pm 1.14 \mathrm{a}$ & $8.14 \pm 0.58 b c$ \\
\hline & MPSRB-20 & $5.02 \pm 0.15 \mathrm{ab}$ & $4.71 \pm 0.16 \mathrm{a}$ & $7.28 \pm 0.31 \mathrm{c}$ & $4.45 \pm 1.59 \mathrm{a}$ & $7.68 \pm 1.41 \mathrm{~cd}$ \\
\hline \multirow[t]{2}{*}{ M. fructicola } & MFC-1 & $8.17 \pm 0.19 b$ & $5.11 \pm 1.13 \mathrm{a}$ & $11.45 \pm 0.06 \mathrm{~cd}$ & $4.72 \pm 0.70 \mathrm{a}$ & $13.67 \pm 0.22 \mathrm{~d}$ \\
\hline & MFC-20 & $8.12 \pm 0.16 b$ & $5.67 \pm 0.8 \mathrm{a}$ & $10.02 \pm 0.11 \mathrm{~cd}$ & $4.49 \pm 0.55 \mathrm{a}$ & $10.17 \pm 0.63 \mathrm{~d}$ \\
\hline \multirow[t]{2}{*}{ M. laxa } & MLX-13 & $5.05 \pm 0.33 b c$ & $3.98 \pm 1.11 \mathrm{a}$ & $6.11 \pm 0.13 \mathrm{~cd}$ & $4.22 \pm 0.90 \mathrm{ab}$ & $10.23 \pm 1.1 \mathrm{e}$ \\
\hline & MLX-24 & $6.43 \pm 0.07 \mathrm{~b}$ & $4.38 \pm 0.94 \mathrm{a}$ & $7.90 \pm 0.10 b c$ & $4.39 \pm 0.52 \mathrm{a}$ & $9.21 \pm 0.29 \mathrm{~cd}$ \\
\hline
\end{tabular}

\footnotetext{
u Values within each row followed by the same letters are not significantly different based on Tukey's test at $P<0.05$. SE: standard error of the mean.

$\checkmark$ Malt extract agar.

${ }^{w}$ Apple juice agar.

x Potato dextrose agar.

y Czapeck Dox agar.

${ }^{\mathrm{z}} \mathrm{V} 8$ juice agar.
} 
could be devastating during the harvest period, but also in storage as well. $M$. polystroma could affect fruit in storage facilities and this finding may have important management implications as postharvest fungicides are not utilized in Serbia via EU regulations.
M. fructicola has been reported as less frequent apple brown rot fungi in Germany, Italy, the Czech Republic, Pennsylvania, and China (Grabke et al. 2011; Martini et al. 2015; OEPP/EPPO 2011; Peter et al 2015; Zhu et al. 2016). In 2011, it was detected as postharvest apple

Table 4. Sporulation intensity of Monilinia spp. isolates on five media at $25^{\circ} \mathrm{C}$ in the dark

\begin{tabular}{|c|c|c|c|c|c|c|}
\hline \multirow[b]{2}{*}{ Species } & \multirow[b]{2}{*}{ Isolate } & \multicolumn{5}{|c|}{ No. of conidia per $\mathrm{cm}^{2}$ of colony $\pm \mathrm{SE}(\log \text { transformed })^{\mathrm{u}}$} \\
\hline & & MEA $^{\mathbf{v}}$ & $\mathbf{A J A}^{\mathbf{w}}$ & PDA $^{\mathbf{x}}$ & CYA $^{\mathbf{y}}$ & $\mathbf{V 8}^{\mathbf{z}}$ \\
\hline \multirow[t]{3}{*}{ M. fructigena } & MFSRB-17 & 0 & 0 & 0 & 0 & 0 \\
\hline & MFSRB-22 & $0 \mathrm{a}$ & $0 \mathrm{a}$ & $0 \mathrm{a}$ & $0 \mathrm{a}$ & $4.37 \pm 1.23 b$ \\
\hline & MFSRB-6 & $0 \mathrm{a}$ & $0 \mathrm{a}$ & $0 \mathrm{a}$ & $0 \mathrm{a}$ & $4.23 \pm 0.17 \mathrm{~b}$ \\
\hline \multirow[t]{3}{*}{ M. polystroma } & MPSRB-36 & $0 \mathrm{a}$ & $0 \mathrm{a}$ & $0 \mathrm{a}$ & $0 \mathrm{a}$ & $4.17 \pm 0.56 \mathrm{~b}$ \\
\hline & MPSRB-13 & $0 \mathrm{a}$ & $0 \mathrm{a}$ & $0 \mathrm{a}$ & $0 \mathrm{a}$ & $4.51 \pm 0.86 \mathrm{~b}$ \\
\hline & MPSRB-20 & $0 \mathrm{a}$ & $0 \mathrm{a}$ & $0 \mathrm{a}$ & $0 \mathrm{a}$ & $4.56 \pm 0.65 b$ \\
\hline \multirow[t]{2}{*}{ M. fructicola } & MFC-1 & $4.49 \pm 0.43 \mathrm{bc}$ & $3.17 \pm 0.57 \mathrm{ab}$ & $4.8 \pm 0.15 \mathrm{~cd}$ & $3.12 \pm 0.67 \mathrm{ab}$ & $4.87 \pm 0.42 \mathrm{~cd}$ \\
\hline & MFC-20 & $4.54 \pm 0.53 b c$ & $3.34 \pm 0.82 \mathrm{ab}$ & $4.93 \pm 0.75 \mathrm{~cd}$ & $3.27 \pm 0.54 \mathrm{ab}$ & $4.95 \pm 0.52 \mathrm{~cd}$ \\
\hline \multirow[t]{2}{*}{ M. laxa } & MLX-13 & $0 \mathrm{a}$ & $0 \mathrm{a}$ & $0 \mathrm{a}$ & $0 \mathrm{a}$ & $3.98 \pm 0.41 b$ \\
\hline & MLX-24 & $0 \mathrm{a}$ & $0 \mathrm{a}$ & $0 \mathrm{a}$ & $0 \mathrm{a}$ & $3.46 \pm 0.24 b$ \\
\hline
\end{tabular}

u Values within each row followed by the same letters are not significantly different based on Tukey's test at $P<0.05$. SE: standard error of the mean.

${ }^{\mathrm{v}}$ Malt extract agar.

${ }^{w}$ Apple juice agar.

${ }^{x}$ Potato dextrose agar.

y Czapeck Dox agar.

z V8 juice agar.

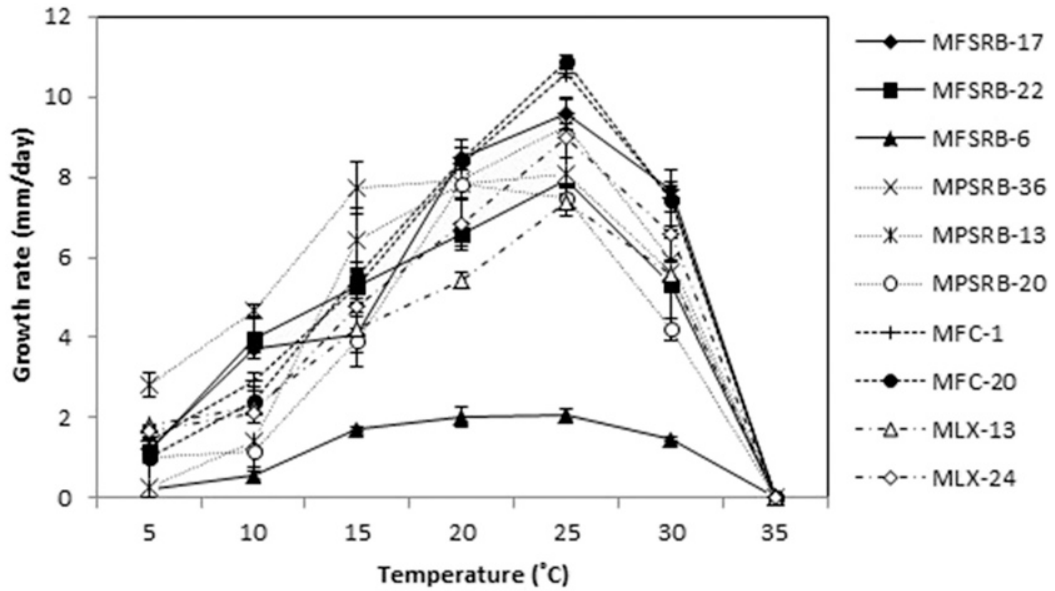

Fig. 4. Effect of temperature on mycelial growth rate of representative M. fructigena isolates (MFSRB-17, MFSRB-22, MFSRB-6), M. polystroma (MPSRB-36, MPSRB-13, MPSRB20), M. fructicola (MFC-1, MFC-20), and M. laxa (MLX-13, MLX-24) on potato dextrose agar in the dark. Vertical bars indicate standard error of mean (SE).

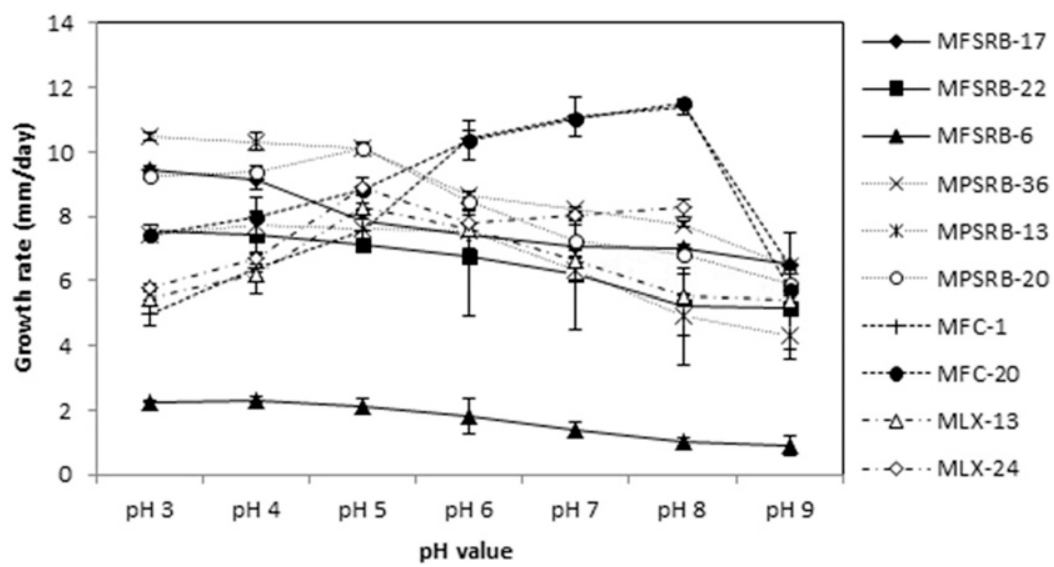

Fig. 5. Effect of pH on mycelial growth rate of $M$. fructigena isolates (MFSRB-17, MFSRB-22, MFSRB-6), M. polystroma (MPSRB-36, MPSRB-13, MPSRB-20), M. fructicola (MFC-1, MFC-20), and M. laxa (MLX-13, MLX-24) on potato dextrose agar at $25^{\circ} \mathrm{C}$ in the dark. Vertical bars indicate standard error of mean (SE). 
pathogen in Serbia (Vasić et al. 2012). Since then, this study indicates the geographic spread of this species. M. fructicola is a pathogen capable of causing latent infections (Michailides et al. 2007), sporulates profusely (Luo et al. 2001), and can easily develop a perfect stage that plays an important role in epidemiology (Hong and Michailides 1998). Its adaptability to higher temperatures according to a study by Papavasileiou et al. (2015) can favor this pathogen. Since global temperatures are increasing, this pathogen could be more harmful for apple fruit production. Also, a recent study by Beckerman et al. (2016) reported severe crop losses over $50 \%$ on apple fruit caused by M. fructicola in Indiana; thus, this pathogen should be monitored in the future as well.

Monilinia spp. can be identified using traditional and molecular methods (Batra 1991; Byrde and Willetts 1977; Côté et al. 2004; OEPP/EPPO 2009). Morphological features are widely used as identification criteria, but they are time consuming and can sometimes be misleading, since variations within a species exist, lending to inaccurate identification. Cultural features of M. polystroma, M. fructicola, $M$. laxa, and one group of $M$. fructigena isolates were in accordance with other reports (Batra 1991; Byrde and Willetts 1977; OEPP/EPPO 2009; van Leeuwen et al. 2002). However, one group of M. fructigena isolates formed stromatal plates in culture, which is similar to M. polystroma. This observation is congruent with what Poniatowska et al. (2013) also noted that Polish isolates of $M$. fructigena formed stromatal plates in vitro. In light of these observations, this morphological feature may not be a reliable diagnostic character to distinguish solely between M. fructigena and M. polystroma.

In this study, we used both traditional and molecular methods for species identification, as molecular techniques are a reliable and accurate tool to confirm species-level identification. Multiplex PCR developed by Côté et al. (2004) facilitated accurate identification and differentiation of $M$. polystroma, M. fructigena, M. fructicola, and M. laxa. Additionally, PCR-RFLP developed by Vasić et al. (2016) was able clearly to separate isolates of $M$. polystroma from other species as an additional layer of species-level confirmation. Phylogenetic analysis of the ITS rDNA sequence, routinely used for Monilinia spp. (Hrustić et al. 2015; Hu et al. 2011; Poniatowska et al. 2013; Zhu et al. 2016), confirmed the species-level identification and revealed that $M$. fructigena and $M$. polystroma are closely related.

Experiments examining fungal growth rate, sporulation, $\mathrm{pH}$, and temperature in vitro for $M$. fructigena, $M$. fructicola, and M. laxa have been examined (Byrde and Willetts 1977). However, there is little knowledge about how these features for M. polystroma compare with other Monilinia spp. that cause apple fruit decay from Serbia. We showed that V8 and PDA were the most favorable media for the growth of all four Monilinia spp. Hu et al. (2011) also observed rapid growth of Chinese isolates of $M$. fructicola, $M$. fructigena, and M. laxa on V8 and PDA. Serbian isolates of M. polystroma, M. fructigena, and M. laxa only sporulated on V8 media, while $\mathrm{Hu}$ et al. (2011) did not observe $M$. fructigena and $M$. laxa sporulation on V8 media, indicating regional/geographic differences in these isolates. Optimal $\mathrm{pH}$ for $M$. polystroma mycelial growth was greater than for $M$. fructigena, as a $\mathrm{pH}$ between 7 and 9 were less favorable for proliferation. Similarly, Holb (2004) noticed that Japanese isolates of $M$. polystroma, originating from apple, grew fastest at $\mathrm{pH}$ 4.5. We observed that optimum temperature for mycelial growth of M. polystroma was $25^{\circ} \mathrm{C}$, which is the first report for temperature
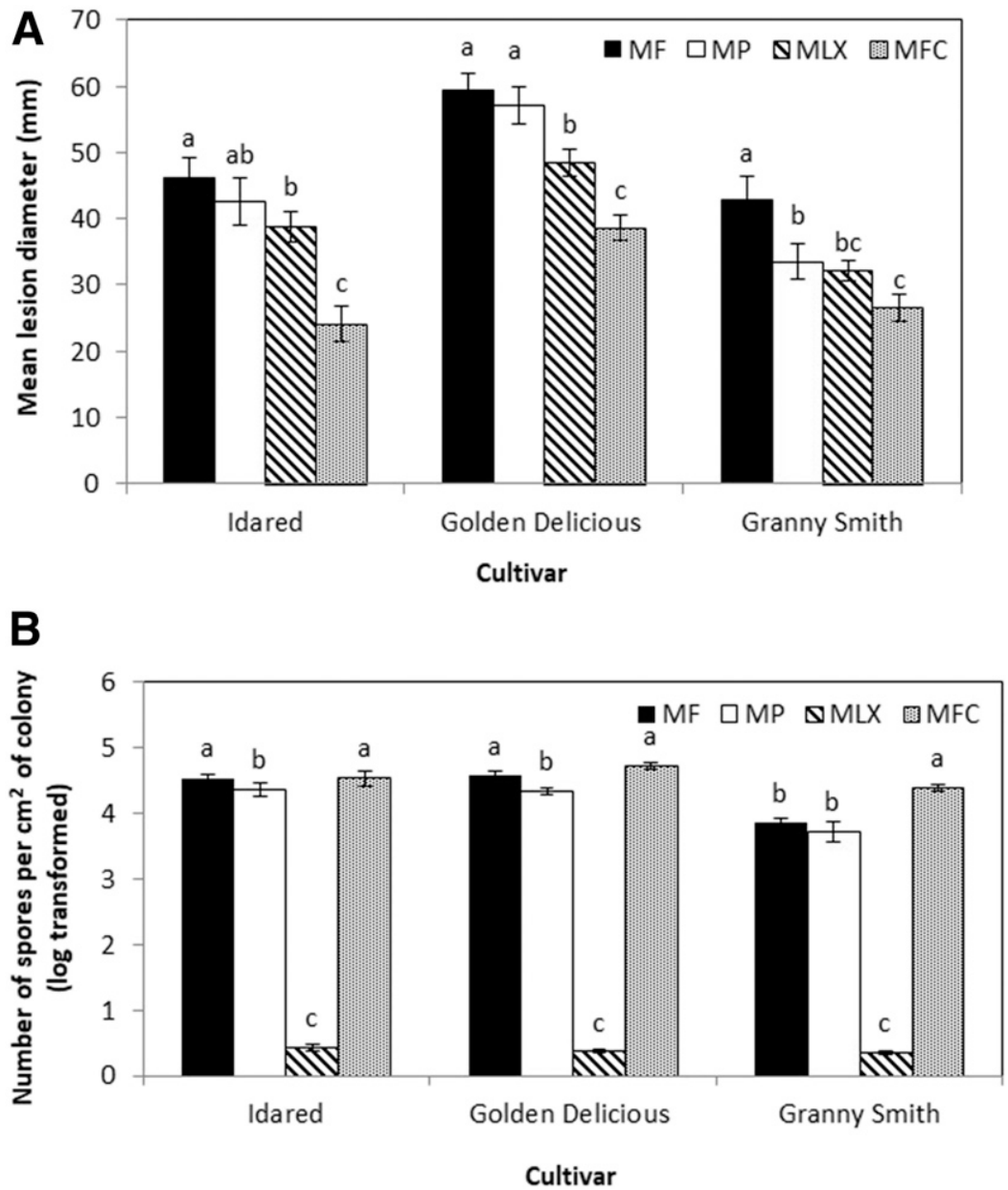

Fig. 6. Mean lesion diameter (A) and sporulation intensity (B) on inoculated apple fruit 'Idared,' 'Golden Delicious,' and 'Granny Smith' with representative isolates of $M$. fructigena (MF), M. polystroma (MP), M. laxa (MLX), and M. fructicola (MFC) after 5 and 6 days of incubation, respectively. Vertical bars represent standard error of mean (SE). 
growth requirements of this species. The same temperature optimum was observed for mycelial growth of other tested species, which is in accordance with the literature for $M$. fructigena, M. fructicola, and M. laxa (Byrde and Willetts 1977).

Comparative analysis of $M$. fructigena, M. polystroma, M. laxa, and $M$. fructicola virulence and sporulation intensity in apple has not been conducted. In our previous investigation, $M$. fructigena was slightly more virulent than M. polystroma on Idared and Granny Smith cultivars, while there was no significant difference in aggressiveness on Golden Delicious (Vasić et al. 2016), which is also in agreement with the current study. M. laxa and M. fructicola were found to be less aggressive overall, which may implicate lower specialization toward apple fruit and may explain why they are more commonly found on stone fruit. Additionally, M. fructigena, M. polystroma, and $M$. fructicola were able to sporulate abundantly on all inoculated apple fruit, indicating their reproductive potential. Similarly, van Leeuwen et al. (2002) showed abundant sporulation of M. fructigena and M. polystroma on 'Conference' pear and 'Cox's Orange Pippin' apple, but quantification of $M$. fructicola sporulation on apple fruit was not conducted. Grabke et al. (2011) observed a zone of sporulation on diseased 'Jonagold' apples and artificially inoculated 'Gala' fruit. Presumably, M. fructicola can sporulate more abundantly and is more prevalent on stone fruit. However, based on our findings, $M$. fructicola has significant inoculum production potential and could compete with $M$. fructigena and $M$. polystroma in fungal-fungal interactions in the orchard.

On the basis of samples collected and isolates obtained during this investigation, we conclude that $M$. fructigena is the main causal agent of apple brown rot pre- and postharvest in Serbia. However, the species composition of brown rot fungi is in flux due to a variety of suspected, yet unknown factors (i.e., differences in host susceptibility, selection pressure exerted by different mode of action fungicides in the field, and varying environmental conditions). Thus, we hypothesize based on increased detection frequency and other competitive factors in the fungus (growth at different temperatures and $\mathrm{pH}$ ) that $M$. polystroma has the potential to compete with $M$. fructigena. The presence of compact stromata on apple fruit coupled with intense melanized hyphal rinds (Vasić et al. 2016) implies that M. polystroma has the potential advantage to survive and produce inoculum compared with other Monilinia spp. Additionally, M. polystroma has a wider $\mathrm{pH}$ optima and higher temperature range than $M$. fructigena, which may contribute to increased adaptability on different hosts in diverse microenvironments. More information about the spread of newly introduced species, changes in pathogen populations, and epidemiology in complex pathosystems is needed to establish adequate disease management strategies.

\section{Acknowledgments}

This research was supported by project III 46008 financed by the Ministry of Education, Technological Development and Science, Republic of Serbia, and partially supported by USDA-ARS project no. 8042-42430-014-00D via National Program 303 Plant Diseases. Use of a company or product name by the U.S. Department of Agriculture does not imply approval or recommendation of the product to the exclusion of others that may also be suitable.

\section{Literature Cited}

Batra, L. R. 1991. World Species of Monilinia (Fungi). Their Ecology, Biosystematics and Control. J. Cramer, Berlin, Germany.

Beckerman, J., Albright, N., and Abbott, C. 2016. First report of brown rot (Monilinia fructicola) on apple (Malus $\times$ domestica). Plant Dis. 100:1949.

Berrie, A. M., and Holb, I. 2014. Brown rot diseases. Pages 43-45 in: Compendium of Apple and Pear Diseases and Pests, 2nd ed. T. B. Sutton, H. S. Aldwinckle, A. M. Angelo, and J. F. Walgenbach, eds. American Phytopathological Society, St. Paul, MN.

Byrde, R. J. W., and Willetts, H. J. 1977. The Brown Rot Fungi of Fruit. Their Biology and Control. Pergamon Press, Oxford.

Côté, M. J., Tardif, M. C., and Meldrum, A. J. 2004. Identification of Monilinia fructigena, M. fructicola, M. laxa, and Monilinia polystroma on inoculated and naturally infected fruit using multiplex PCR. Plant Dis. 88:1219-1225.

Day, J. P., and Shattock, R. C. 1997. Aggressiveness and other factors relating to displacement of populations of Phytophthora infestans in England and Wales. Eur. J. Plant Pathol. 103:379-391.
Di Francesco, A., Fruk, M., Martini, C., Jemrić, T., and Mari, M. 2015. First report of Asiatic brown rot (Monilinia polystroma) on apple in Croatia. Plant Dis. 99: 1181-1182.

EFSA Panel. 2011. Pest risk assessment of Monilinia fructicola for EU territory and identification and evaluation of risk management options. EFSA J. 9:2119.

Gams, W., van der Aa, H. A., van der Plaats-Niterink, A. J., Samson, R. A., and Stalpers, J. A. 1987. Page 136 in: CBS Course of Mycology. 3rd edition. Institute of Royal Netherlands Academy of Arts and Sciences, Centraalbureau voor Schimmelcultures, Baarn, Netherlands.

Grabke, A., Hu, M. J., Luo, C. X., Bryson, P. K., and Schnabel, G. 2011. First report of brown rot of apple caused by Monilinia fructicola in Germany. Plant Dis. 95:772.

Harada, Y., Nakao, S., Sasaki, M., Sasaki, Y., Ichihashi, Y., and Sano, T. 2004. Monilinia mumecola, a new brown rot fungus on Prunus mume in Japan. J. Gen. Plant Pathol. 70:297-307.

Holb, I. J. 2004. Effect of acidity on growth rate and stroma formation of Monilinia fructigena and M. polystroma isolates. Int. J. Hortic. Sci. 10:63-67.

Holb, I. J., and Chauhan, S. V. S. 2004. Effect of carbohydrate and nitrogen sources on the growth rates of Monilinia fructigena and M. polystroma isolates. J. Mycol. Plant Pathol. 35:128-131.

Holb, I. J., and Scherm, H. 2007. Temporal dynamics of brown rot in different apple management systems and importance of dropped fruit for disease development. Phytopathology 97:1104-1111.

Hong, C., and Michailides, M. J. 1998. Effect of temperature on the discharge and germination of ascospores by apothecia of M. fructicola. Plant Dis. 82:195-202.

Hrustić, J., Delibašić, G., Stanković, I., Grahovac, M., Krstić, B., Bulajić, A., and Tanović, B. 2015. Monilinia spp. causing brown rot of stone fruit in Serbia. Plant Dis. 99:709-717.

Hrustić, J., Tanović, B., Mihajlović, M., Delibašić, G., Stanković, I., Krstić, B., and Bulajić, A. 2013. First report of brown rot caused by Monilinia fructicola on nectarine in Serbia. Plant Dis. 97:147.

Hu, M. J., Cox, D. C., Schnabel, G., and Luo, C. X. 2011. Monilinia species causing brown rot of peach in China. PLoS One 6:e24990.

Ivanović, M., and Ivanović, D. 2001. Mikoze i Pseudomikoze Biljaka. De-Em-Ve, Belgrade, Serbia.

Kim, Y. K., Xiao, C. L., and Rogers, J. D. 2005. Influence of culture media and environmental factors on mycelial growth and pycnidial production of Sphaeropsis pyriputrescens. Mycologia 97:25-32.

Luo, Y., Ma, Z., and Michailides, T. J. 2001. Analysis of factors affecting latent infection and sporulation of Monilinia fructicola on prune fruit. Plant Dis. 85:999-1003

Martini, M., Di Francesco, A., Lantos, A., and Mari, M. 2015. First report of Asiatic brown rot (Monilinia polystroma) and brown rot (Monilinia fructicola) on pears in Italy. Plant Dis. 99:556.

Michailides, T. J., Luo, Y., Ma, Z., and Morgan, D. P. 2007. Brown rot of dried plum in California: new insight on an old disease. APSnet Feature.

Michailides, T. J., Ogawa, J. M., and Opgenorth, D. C. 1987. Shift of Monilinia spp. and distribution of isolates sensitive and resistant to benomyl in California prune and apricot orchards. Plant Dis. 71:893-896.

Munda, A. 2015. First report of brown rot on peach caused by Monilinia polystroma in Slovenia. Plant Dis. 99:1281.

OEPP/EPPO. 2002. First report of Monilinia fructicola in France. EPPO Reporting Service 2002/003. http://archives.eppo.int/EPPOReporting/2002/Rse-0201.pdf OEPP/EPPO. 2009. Monilinia fructicola. Bull. OEPP/EPPO Bull. 39:337-343.

OEPP/EPPO. 2011. First reports of Monilinia polystroma in Hungary and the Czech Republic. EPPO Reporting Service. https://gd.eppo.int/reporting/article1703

Papavasileiou, A., Testempasis, S., Michailides, T. J., and Karaoglanidis, G. S. 2015. Frequency of brown rot fungi on blossoms and fruit in stone fruit orchards in Greece. Plant Pathol. 64:416-424.

Peter, K., Gaskin, V., Lehman, B., and Jurick, W. 2015. First report of brown rot caused by Monilinia fructicola in Pennsylvania. Plant Dis. 99:1179.

Petróczy, M., and Palkovics, L. 2009. First report of Monilinia polystroma on apple in Hungary. Eur. J. Plant Pathol. 125:343-347.

Poniatowska, A., Michalecka, M., and Bielenin, A. 2013. Characteristic of Monilinia spp. fungi causing brown rot of pome and stone fruits in Poland. Eur. J. Plant Pathol. 135:855-865.

Poniatowska, A., Michalecka, M., and Puławska, J. 2016. Genetic diversity and pathogenicity of Monilinia polystroma - the new pathogen of cherries. Plant Pathol. 65:723-733.

Staden, R., Beal, K. F., and Bonfield, J. K. 2000. The Staden package, 1998. Methods Mol. Biol. 132:115-130.

Tamura, K., Stecher, G., Peterson, D., Filipski, A., and Kumar, S. 2013. MEGA6: Molecular evolutionary genetics analysis version 6.0. Mol. Biol. Evol. 30: $2725-2729$

Thompson, J. D., Gibson, T. J., Plewniak, F., Jeanmougin, F., and Higgins, D. G 1997. The Clustal X windows interface: flexible strategies for multiple sequence alignment aided by quality analysis tools. Nucleic Acids Res. 25: 4876-4882.

van Leeuwen, G. C. M., Baayen, B. P., Holb, I. J., and Jeger, M. J. 2002. Distinction of the Asiatic brown rot fungus Monilinia polystroma sp. nov. from M. fructigena. Mycol. Res. 106:444-451. 
van Leeuwen, G. C. M., Stein, A., Holb, I., and Jeger, M. J. 2000. Yield loss in apple caused by Monilinia fructigena (Aderh. \& Ruhl.) Honey, and spatiotemporal dynamics of disease development. Eur. J. Plant Pathol. 106:519-528.

Vasić, M., Duduk, N., and Ivanović, M. 2013. First report of brown rot caused by Monilinia polystroma on apple in Serbia. Plant Dis. 97:145.

Vasić, M., Duduk, N., Ivanović, M. M., Obradović, A., and Ivanović, M. S. 2012. First report of brown rot caused by Monilinia fructicola on stored apple in Serbia. Plant Dis. 96:456.

Vasić, M., Duduk, N., Vico, I., Rančić, D., Pajić, V., and Backhouse, D. 2016. Comparative study of Monilinia fructigena and Monilinia polystroma on morphological features, pathogenicity, RFLP analysis and histopathology. Eur. J. Plant Pathol. 144:15-30.
Villarino, M., Egüen, B., Lamarca, N., Seggera, J., Usall, J., Melgarejo, P., and De Cal, A. 2013. Occurrence of Monilinia laxa and M. fructigena after introduction of M. fructicola in peach orchards in Spain. Eur. J. Plant Pathol. 137:835-845.

White, T. J., Bruns, T., Lee, S., and Taylor, J. 1990. Amplification and direct sequencing of fungal ribosomal RNA genes for phylogenetics. Pages 315-322 in: PCR Protocols: A Guide to Methods and Applications. M. A. Innis, D. H. Gelfand, J. J. Sninsky, and T. J. White, eds. Academic Press, San Diego, CA.

Zhu, X. Q., Chen, X. Y., and Guo, L. Y. 2011. Population structure of brown rot fungi on stone fruits in China. Plant Dis. 95:1284-1291.

Zhu, X. Q., Niu, C. W., Chen, X. Y., and Guo, L. Y. 2016. Monilinia species associated with brown rot of cultivated apple and pear fruit in China. Plan Dis. 100:2240-2250. 